\title{
KRITIK KUALITAS MATAN HADIS PEREMPUAN LEMAH AKALNYA PERSPEKTIF SALAHUDIN IBN AHMAD AL-ADLABI
}

\author{
Atiyatul Ulya \\ Universitas Islam Negeri Syarif Hidayatullah Jakarta, Indonesia \\ athiya_ulya@yahoo.com
}

\begin{abstract}
Islam glorifies women, there are even many verses of the Qur'an and hadith that indicate that women are the same creatures as men. However, there is a tradition that justifies that women are a creature with a weak mind, ess religion and most hell dwellers. Stigma or justification of women is very contrary to the general picture of women in the Prophet Muhammad SAW intelligent. This article is a critical analysis of the re-reading of the tradition which states women are weak. By using the methodology of matan's criticism Salahudin ibn Ahmad al-Adlabi, the quality of the hadith matan is known not to meet the criteria of Matan's.
\end{abstract}

Keywords: Hadîth, Woman, Mind

\begin{abstract}
Abstrak
Islam sangat memuliakan perempuan, bahkan terdapat banyak ayat al-Qur'an dan hadis yang menyatakan bahwa perempuan adalah makhluk mulia dan sama seperti laki-laki. Namun, terdapat sebuah hadis yang menjustifikasi bahwa kaum perempuan adalah makhluk yang lemah akalnya, kurang agamanya dan penghuni neraka terbanyak. Stigma atau justifikasi terhadap perempuan tersebut sangat bertolak belakang dengan gambaran umum tentang perempuan pada masa Rasulullah SAW yang cerdas dan berakal. Untuk mengetahui keotentikan hadis tersebut, maka perlu sekali dilakukan pengkajian hadis terutama dari segi matan. Dari beberapa metode kritik matan yang ada, teori tentang ke-sahîh-an matan yang relatif memadai adalah metodologi Salahudin ibn Ahmad al-Adlabi. Setelah melakukan pengkajian hadis berdasarkan metodologi tersebut, maka disimpulkan bahwa kualitas matan hadis tersebut tidak memenuhi kriteria ke-șahîh-an matan hadis.
\end{abstract}

Kata Kunci: Hadis, Perempuan, Akal

\section{Pendahuluan}

Dalam beberapa riwayat hadis dijelaskan bahwa perempuan memperoleh posisi terhormat pada masa Rasulullah SAW. Umar bin Khattab bahkan memberi kesaksian dalam hal ini, sebagaimana yang diriwayatkan dalam $\underline{S} a \underline{h} \hat{\imath} \underline{h}$ Bukhârî berikut:

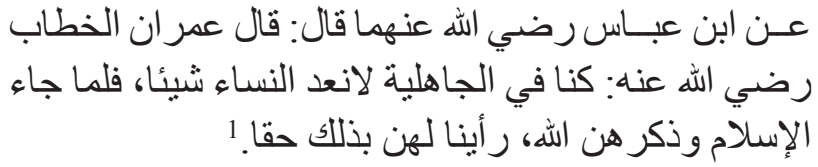

${ }^{1}$ Abî 'Abdillâh Muhammad bin Ismâ'îl bin Ibrâhîm bin alMughîrah al-Ju'fî̀ Al-Bukhârî, $\underline{S} a \underline{h} \underline{i} \underline{h}$ al-Bukhârî (Riyâd: Maktabah al-Rasyid, 2006), no. 5843. 
Artinya: “... dulu kami pada masa Jahiliyah, tidak memperhitungkan perempuan sama sekali. Ketika Islam turun, dan Allah SWT mengakui mereka, kemudian kami memandang bahwa mereka pun memiliki hak atas kami."

Perempuan mendapat perlakuan yang tidak berbeda dengan laki-laki, tidak diperjualbelikan atau tidak dianggap sebagai setengah manusia (separuh dari laki-laki). Perempuan pada masa Nabi juga memiliki peran besar dalam periwayatan hadis. Bahkan sepanjang sejarah periwayatan hadis, masa Nabi adalah masa dimana jumlah perempuan periwayat hadis memiliki jumlah paling banyak.

Agung Danarta yang menjelaskan bahwa tidak kurang dari 50 perempuan yang berstatus sebagai sahabat telah terlibat dalam periwayatan hadis. Bahkan dari penelitian yang dilakukan oleh Agung Danarta menunjukkan jumlah yang lebih besar yaitu 132 orang sahabat perempuan terlibat dalam periwayatan hadis pada masa Rasulullah SAW. ${ }^{2}$

Di antara para perempuan periwayat hadis yang ada pada masa Rasulullah SAW, para istri Nabi terlihat yang paling banyak meriwayatkan hadis. 'Âisyah dan Ummu Salamah adalah istri Nabi yang paling banyak meriwayatkan hadis. ${ }^{3}$ Selain para istri Nabi, beberapa sahabat perempuan juga tercatat sebagai periwayat hadis, seperti Zainab binti Abî Salâmah, Asmâ' binti Abû Bakar, Ummu 'Athiyah, Fâtimah binti Abî Tâlib atau Ummu Hani', Fâtimah binti Qays dan sebagainya.

'Âisyah dan Ummu Salamah juga dikenal sebagai rujukan para sahabat dalam meng-kroscek riwayat yang mereka dengar. 'Âisyah juga selalu

\footnotetext{
${ }^{2}$ Agung Danarta, Perempuan Periwayat Hadis (Yogyakarta: Pustaka Pelakar, 2013), 6.

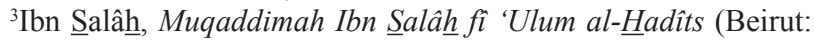
Dâr al-Kutub al-'Ilmiyyah, t.t), 177.

${ }^{4}$ Para sahabat pernah meng-kroscek kepada 'Âisyah dan Ummu Salamah tentang riwayat yang diperoleh dari Abû Hurairah, bahwa orang yng sedang junub sampai pagi belum bersuci, maka puasanya batal. 'Âisyah dan Ummu Salamah mengklarifikasi riwayat tersebut bahwa mereka pernah melihat Nabi SAW junub pada malam hari sampai pagi karena jima', Nabi SAW tetap melanjutkan puasanya. Lihat: Muhammad 'Abid al-Sanadî, Tartîb Musnad al-Imâm alSyâfi'î, no. 694 (Beirut: Dâr al-Fikr, 1997), 168.
}

menanyakan kepada Nabi Muhammad SAW akan segala sesuatu yang tidak dipahami dengan baik. ${ }^{5}$

Nabi SAW juga biasa meminta pendapat para istrinya tentang berbagai hal, sebagaimana yang pernah dilakukan kepada Ummu Salamah pada peristiwa Hudaibiyah. Ketika selesai penulisan perjanjian Hudaibiyah, Rasulullah SAW memerintahkan para sahabat untuk mencukur rambut (tahallul) dan menyembelih hewan kurban. Akan tetapi tidak satupun sahabat yang menghiraukan perintah Rasulullah SAW tersebut. Beliau lalu menemui Ummu Salamah dan menceritakan apa yang sedang dialami. Ummu Salamah kemudian memberikan saran supaya Rasulullah SAW mencukur rambutnya dan menyembelih hewan kurbannya tanpa mengatakan apa-apa kepada para sahabat. Rasulullah SAW mengikuti saran yang disampaikan oleh Ummu Salamah. ${ }^{6}$

Dalam hal ini A. Shallabi berkomentar bahwa peristiwa tersebut menunjukkan Islam tidak membedakan apakah sebuah masukan pendapat berasal dari laki-laki atau perempuan selama masukan tersebut adalah masukan yang benar. Bahkan hal ini merupakan bentuk penghormatan kepada wanita yang dianggap oleh musuhmusuh Islam hak-hak mereka dihilangkan dan keberadaan mereka tidak dianggap. ${ }^{7}$

Para perempuan ketika masa Rasulullah SAW juga menuntut diberikan pengajaran tersendiri sebagaimana yang juga dilakukan Rasulullah SAW terhadap laki-laki. Beberapa riwayat hadis juga menggambarkan bagaimana perempuanperempuan berpartisipasi dalam dunia pemikiran Islam dan praktik keagamaan, mengomentari secara fair dalam topik apapun. Al-Tabâri, sebagaimana dikutip oleh M. Hadi Masruri menjelaskan tentang sikap protes dan menuntut keadilan yang ditunjukkan oleh para perempuan

\footnotetext{
${ }^{5}$ Abî 'Abdillâh Muhammad bin Ismâ'îl, $\underline{S} a \underline{h} \underline{h} \underline{h}$ al-Bukhârî, kitab al-'Ilm, no. 103.

${ }^{6}$ Ibid., Kitab al-Syurut, no. 2371 dan 2732.

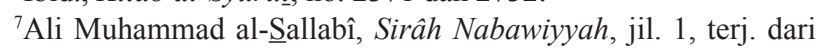
bahasa Arab oleh Imam Fauji (Jakarta: Beirut Publishing, 2014), 878 .
} 
kepada Nabi Muhammad, mengapa dalam alQur'an hanya menyeru kaum pria dan pada saat yang sama para perempuan harus memenuhi seruan Allah dan Rasul-Nya. Sikap protes ini tentu dilatarbelakangi adanya pandangan dalam masyarakat Islam saat itu bahwa kaum pria mengungguli perempuan dalam hak-haknya, terutama pengetahuan agama. Mereka juga meminta kepada Nabi Muhammad untuk memberikan tambahan waktu untuk mengajar mereka, sehingga dapat menyamai kaum pria. Menurut suatu riwayat diceritakan bahwa Ummu Salamah mewakili kaumnya bertanya kepada Nabi Muhammad: "Kenapa kaum laki-laki selalu disebut di dalam al-Qur'an, dan kami para perempuan tidak demikian?" Pertanyaan Ummu Salamah tersebut kemudian terjawab dengan turunnya Surat al-A hzzâb ayat 35-36 yang didengar langsung oleh Ummu Salamah ketika Nabi SAW di mimbar membacakan ayat tersebut. ${ }^{8}$

Uraian di atas menjelaskan bahwa para sahabat perempuan adalah orang-orang yang cerdas, smart, dan berakhlak mulia. Sementara dalam satu riwayat yang dinilai $\underline{s} a \underline{h} \underline{h} \underline{h}$ dan diriwayatkan dalam jalur yang cukup banyak, justru Nabi SAW menyatakan bahwa perempuan adalah makhluk yang lemah akalnya, sebagaimana dalam hadis yang terdapat dalam Sunan Ibnu Mâjah no. 4138 sebagai berikut: ${ }^{9}$

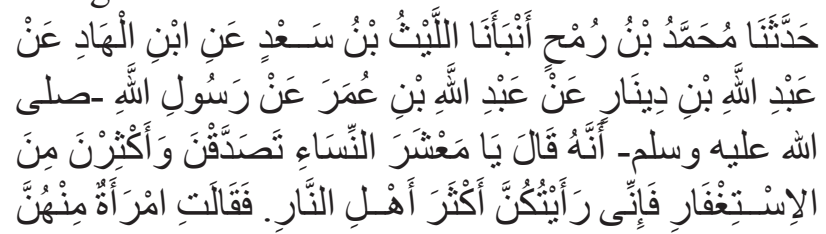

${ }^{8}$ M. Hadi Masruri, "Peran Sosial Perempuan dalam Islam Kajian Historis-Normatif," dalam Egalita Jurnal Kesetaraan dan Keadilan Gender VII, no. 1 (2012): 22-42.

${ }^{9}$ Sanad hadis ini diperoleh dari 5 sahabat, yaitu Abû Sa'îd alKhudrî, Ibn 'Abbâs, Ibn 'Umar, Abû Hurayrah, dan Ibn Mas'ûd, dengan banyak sekali jalur periwayatan yang ditulis dalam kitab hadis muktabar seperti al-Bukhârî, Muslim, al-Tirmidzî, Ibn Mâjah dan Ahmad. Uraian selengkapnya tentang riwayat hadis ini, lihat misalnya al-Bukhârî, al-Jâmi', vol.2, 45; Muslim, al-Jâmi', vol.1, 61; Abû 'Abd Allâh Muhammad ibn Yazîd al-Qazwaynî ibn Mâjah (w. 275 H.), S Sahîh $\underline{h}$ Sunan Ibn Mâjah, dalam: Muhammad Nâsir al-Dîn al-Albânî, cet.1, vol.3, (Riyâdh: Maktabah al-Ma'ârif, 1997 M/1417 H), 312; al-Tirmidzî, alJâmi', 589; Ahmad, Musnad, vol.1, 376, 436.

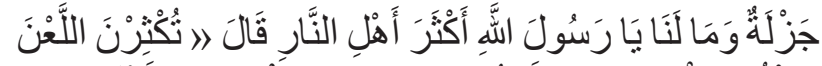

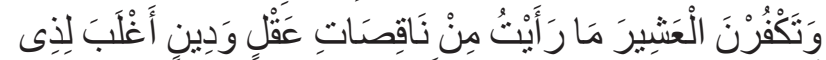

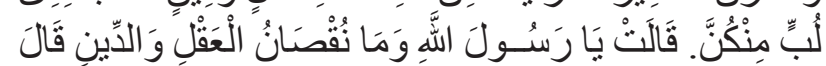

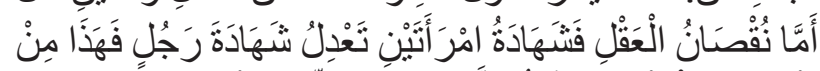

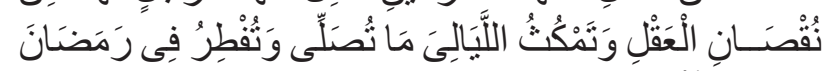

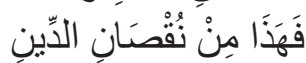

“... Wahai para wanita, bersedekahlah kalian dan perbanyaklah istighfar, karena aku melihat mayoritas penghuni neraka adalah kalian." Salah seorang wanita cerdik di antara mereka bertanya, "Wahai Rasulullah, mengapa kebanyakan kami menjadi mayoritas penghuni neraka?" Beliau menjawab, "(Karena) kalian sering melaknat dan mengingkari (kebaikan) suami, dan tidaklah aku pernah melihat (seseorang di antara kalian para wanita yang lemah akal dan agamanya, lebih berakal dari (seorang laki-laki) yang berakal, " Wanita itu bertanya lagi, "Apa maksud dari kekurangan akal dan agama?” Beliaupun menjawab, "Adapun kelemahan akal, karena persaksian dua orang wanita sebanding dengan persaksian seorang laki-laki, inilah (tanda) kurangnya akal, serta kalian berdiam selama beberapa hari tidak melaksanakan shalat, serta berbuka (di siang hari) Ramadhan. Inilah kurangnya agama”.

Hadis di atas memiliki 9 buah sanad. Lima sanadnya bersumber dari Abû Said al-Khudry, tiga sanad dari 'Abdullâh Ibnu Umar dan satu sanad bersumber dari Abû Hurairah. Semua periwayatnya laki-laki, tidak satupun melibatkan periwayat perempuan.

Secara teks, hadis di atas menjustifikasi bahwa kaum perempuan adalah makhluk yang lemah akalnya, kurang agamanya dan penghuni neraka terbanyak. Stigma atau justifikasi terhadap perempuan tersebut sangat bertolak belakang dengan gambaran umum tentang perempuan pada masa Rasulullah SAW yang cerdas dan berakal. 
Oleh karena itu, tidak berlebihan ketika ungkapan Nabi SAW dalam hadis tersebut menimbulkan pertanyaan, bahkan oleh sahabat perempuan yang cerdas sekalipun sebagaimana yang terungkap dalam hadis tersebut. Secara logika, Rasulullah SAW sebagai orang yang paling santun akhlaknya dibanding siapapun, tidak mungkin melontarkan pernyataan yang "merendahkan" kaum perempuan dengan mengatakan mereka adalah makhluk yang paling lemah akalnya dan kurang agamanya. ${ }^{10}$

Pemahaman terhadap hadis tersebut menarik untuk didiskusikan dan dikaji agar stigma bahwa perempuan lemah akalnya bisa dibuktikan keotentikan matannya. Sementara dalam beberapa riwayat hadis $\underline{s} a \underline{h} \underline{i} \underline{h}$ di atas maupun dari ayat alQur'an menjelaskan dan menggambarkan bahwa semua manusia, lelaki dan perempuan, adalah setara di hadapan Allah. Tentu saja pandangan yang mencerminkan ketidaksetaraan di atas sangat menyedihkan dan dapat berkembang menjadi pandangan yang inferior, diskriminatif, dan misoginis bahwa seolah perempuan setengah manusia laki-laki, posisi dan kualitas perempuan lebih rendah ketimbang laki-laki, dan perempuan kurang bisa dipercaya secara penuh dalam urusan apapun karena lemah akalnya dan kurang agamanya.

Oleh karena itu, penelitian ini ingin mengkaji lebih lanjut tentang keotentikan matan hadis ini dengan menggunakan teori ke-s $a \underline{h} \underline{h} \underline{h}$-an matan yang dikemukakan oleh al-Adlabi.

Teori Penelitian ini akan menitikberatkan pada penelitian kajian ke-s $a \underline{h} \underline{\hat{h}} \underline{h}$-an matan. Perspektif al-Adlabi ini dipilih karena metodenya yang tepat digunakan untuk membahas validitas sebuah hadis. Selain itu, karena adanya pertimbangan bahwa teori tentang ke-s $a \underline{h} \hat{i} \underline{h}$-an matan yang relatif memadai adalah karya al-Adlabi yang akan dijadikan landasan teori dalam penelitian ini.

${ }^{10}$ Lia Aliyah al-Himmah, "Kesaksian Perempuan, Benarkah Separuh Laki-laki?," dalam SUPLEMEN Edisi 06, Swara Rahima VIII, no. 25 (2008): 19-20.

\section{Metodologi Kritik Matan Salahudin ibn}

\section{Ahmad al-Adlabi}

Salah satu teori atau metodologi untuk mengkritik hadis dari segi matan adalah yang dikemukakan oleh Salahudin ibn Ahmad alAdlabi dalam bukunya Manhaj Naqdu al-Matn 'Inda 'Ulamâ al-Hadîts al-Nabawî. Buku ini telah diterjemahkan oleh Qodirun Nur dan Ahmad Musyafiq dengan judul Metodologi Kritik Matan Hadis. Dalam buku tersebut, Salahudin ibn Ahmad al-Adlabi mengemukakan empat kategori dalam menilai ke-sahîh $\underline{h}$-an matan hadis, yaitu:

1. Matan hadis tidak bertentangan dengan ayatayat al-Qur'an;

2. Tidak bertentangan dengan hadis $\underline{s} a \underline{h} \underline{h} \underline{h}$ dan sirah nabawiyah yang $\underline{s} a \underline{h} \underline{i} \underline{h}$;

3. Tidak bertentangan dengan akal, indra dan sejarah;

4. Matan hadis tidak menunjukkan ungkapan yang serampangan, atau tidak menunjukkan makna yang rendah. ${ }^{11}$

Kerangka teori ke-s $a \underline{h} \underline{h} \underline{h}$-an matan yang dikemukakan oleh al-Adlabi ini sengaja dipilih dengan pertimbangan bahwa dalam sejarah 'ulum al-hadits, metode kritik matan yang dikemukakan oleh para ulama hadis, pada umumnya tetap terfokus pada penelitian sanad. Sementara karya yang meneliti tentang matan seperti kitab alManâr al-Munîf karya Ibn al-Qayyim (w. 751 H), dan kitab al-Ijâbah fí mâ Istadrakathu al-Sayyidah

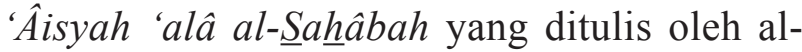
Zarkasyi, masih terbatas isinya bila dikaitkan dengan kebutuhan akan penelitian terhadap matan hadis. Teori tentang ke-s $a \underline{h} \underline{i} \underline{h}$-an matan yang relatif memadai setelah dua kitab tersebut di atas, adalah karya al-Adlabi yang akan dijadikan landasan teori dalam penelitian ini. Kajian atau penelitian terhadap matan hadis ini sangat

\footnotetext{
"Salâh al-Dîn ibn Ahmad al-Adabî, Manhaj Naqd al-Matn 'inda 'Ulamâ al-Hadîts al-Nabawî̀ (Beirut: Dâr al-Ifaq alJadîdah, 1983), 225-358. Lihat juga, Salahudin ibn Ahmad alAdlabi, Metodologi Kritik Matan Hadis, terj. dari bahasa Arab oleh Qodirun Nur dan Ahmad Musyafiq (Jakarta: Gaya Media Pratama, 2004), 197-280.
} 
penting agar kita tidak terjebak pada penelitian hadis berdasar pada sanad saja, "mengabaikan" penelitian matan, atau sebaliknya, terjebak pada penelitian matan saja, "mengabaikan" pada kajian sanad.

\section{Takhrîj Hadis Perempuan Lemah Akal}

Dari hasil penelusuran terhadap kitab-kitab induk hadis, hadis yang menjelaskan tentang perempuan lemah akalnya diriwayatkan dalam delapan kitab induk hadis dengan jalur sanad yang berbeda-beda. Delapan kitab induk hadis itu adalah kitab $\underline{S} a \underline{h} \underline{\hat{h}} \underline{\mathrm{h}}$ al-Bukhârî, Musnad A $\underline{h}$ mad Ibn $\underline{H}$ anbal, $\underline{S} a \underline{h} \underline{i} \underline{h}$ Muslim, Sunan Ibnu Mâjah, Sunan al-Tirmidzî, Sunan Abû Dâwud, Sunan alNasâ 'i, dan Sunan al-Dârimî. ${ }^{12}$ Teks hadis secara lengkap sebagaimana berikut:

1. Kitab $\underline{S} a \underline{h} \underline{h} \underline{h}$ al-Bukhârî Bab Tark al-Khaidli al-Sauma

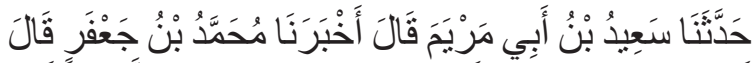

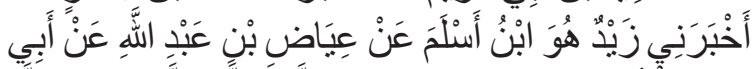

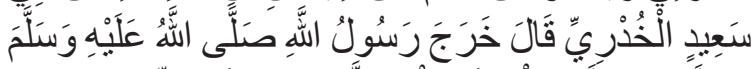

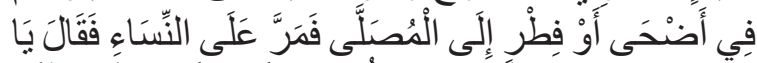

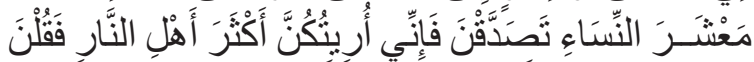

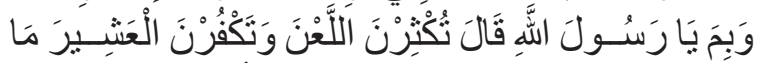

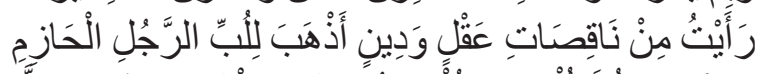

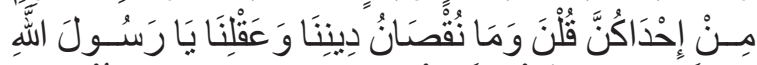

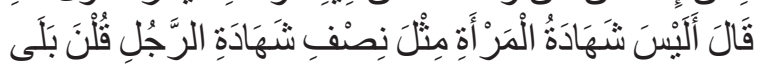

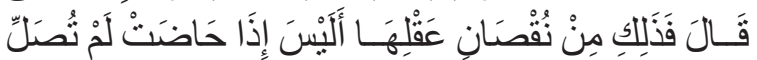

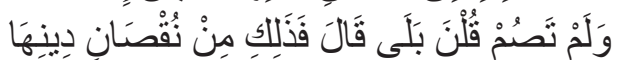

2. Kitab $\underline{S} a \underline{h} \underline{i} \underline{h}$ al-Bukhârî Bab Syahadah alNisấ

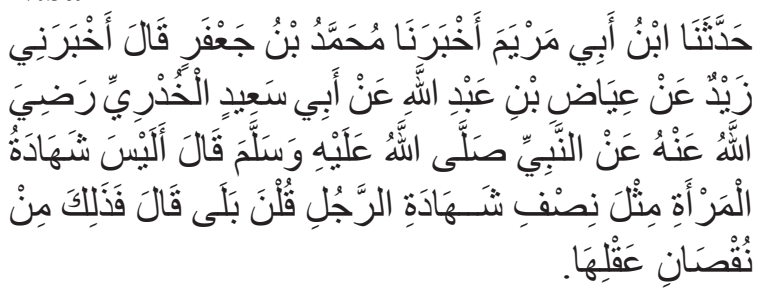

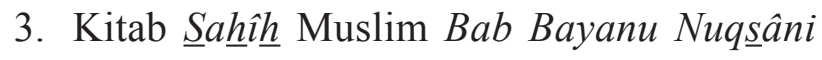

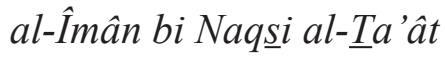

${ }^{12}$ Winsink, Al-Mu'jam al-Mufahras Lialfâz al- $\underline{\text { Hadîts }}$ alNabawwî (Leiden: Beril, 1936).

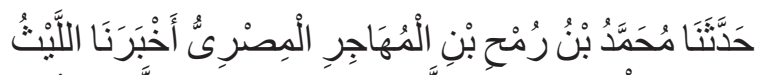

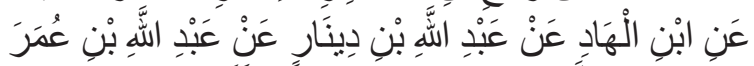

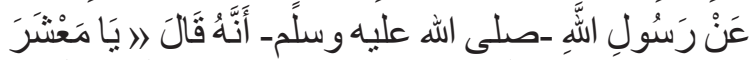

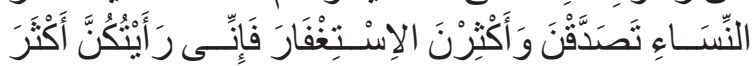

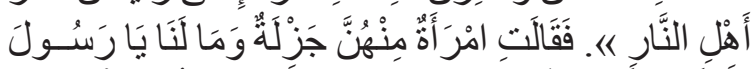

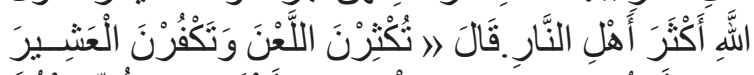

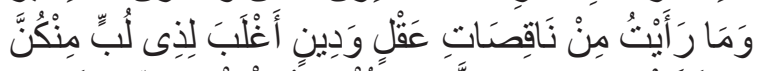

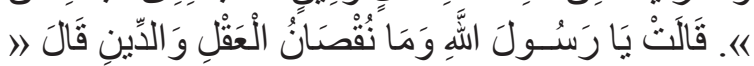

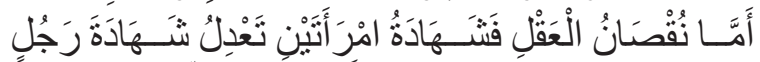

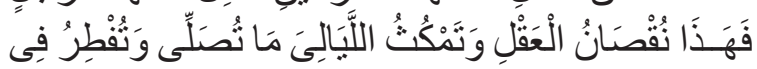

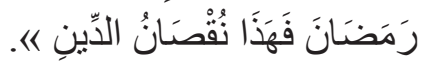

4. Kitab Sunan Abû Dâwud Bab al-Dalîl 'alâ Ziyâdah al-Îmân wa Nuqsânihi

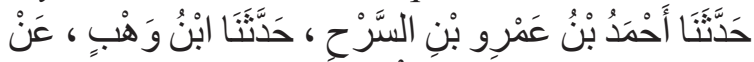

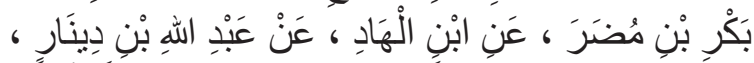

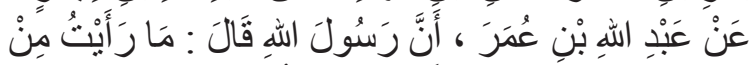

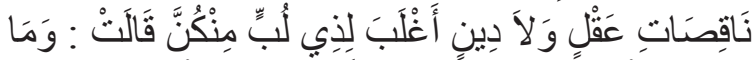

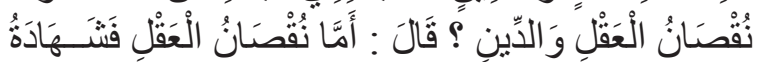

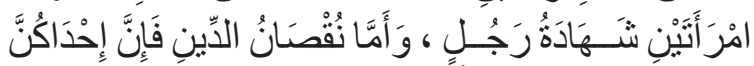

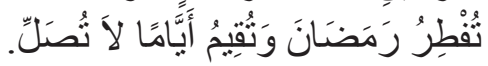

5. Kitab Sunan al-Turmudzî Bab ma jâ' $a$ fî Istikmâl al-Îmân wa Ziyâdatihi wa Nuqsânihi

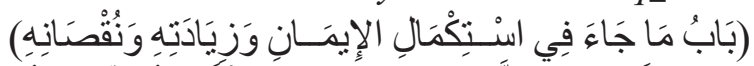

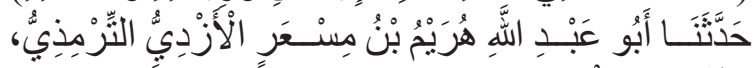

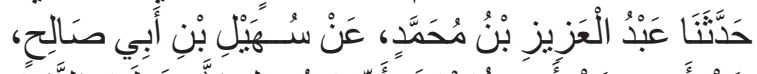

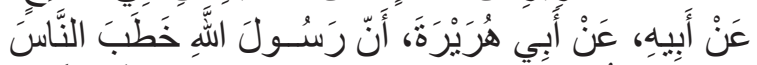

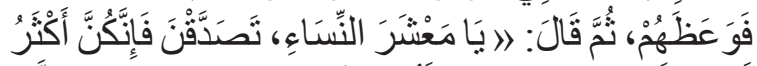

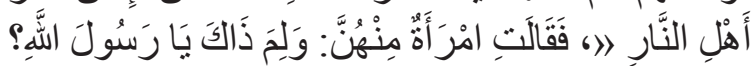

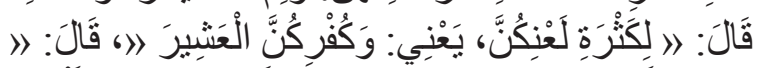

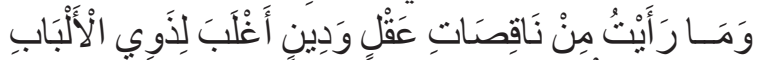

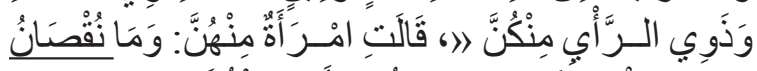

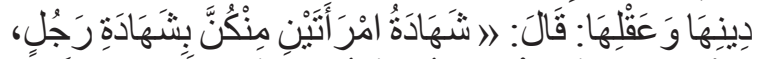

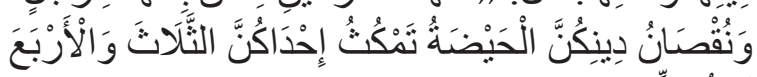
لَا تُصَلِّي.

6. Kitab Sunan al-Kubrâ li al-Nasâ'i 8928

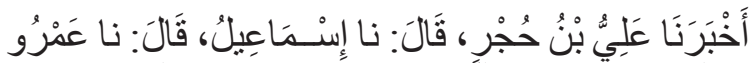

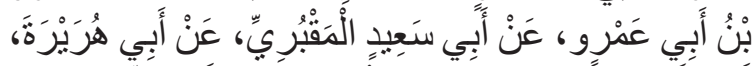

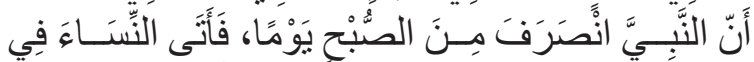

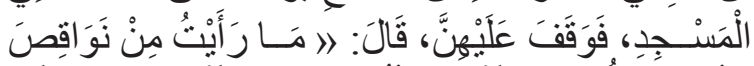

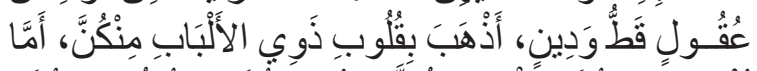

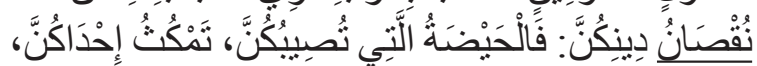




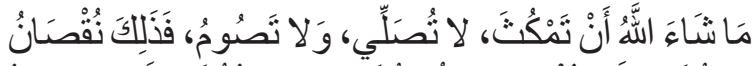

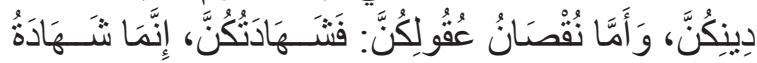

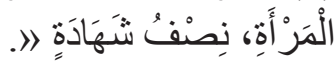

7. Kitab Sunan Ibnu Mâjah Bab Fitnah al-Nisâ '

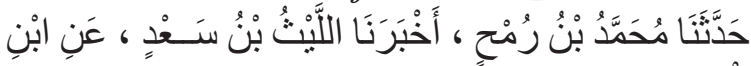

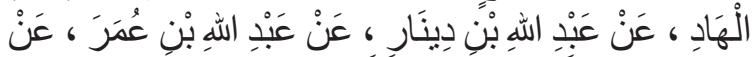

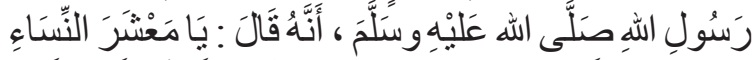

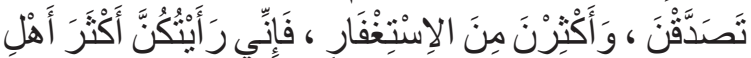

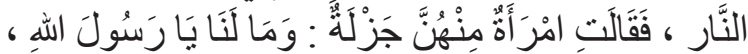

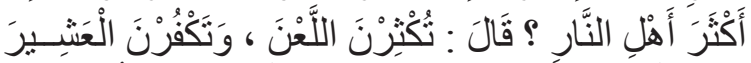

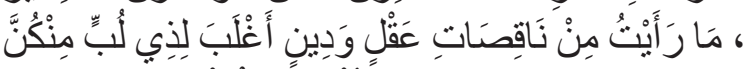

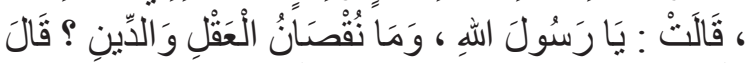

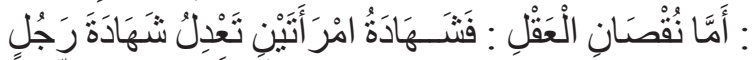

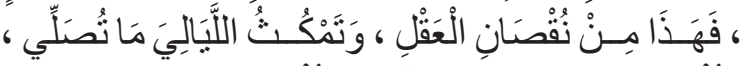

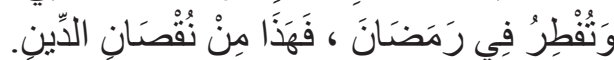

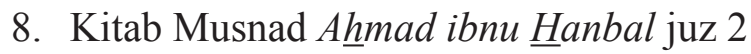

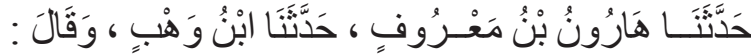

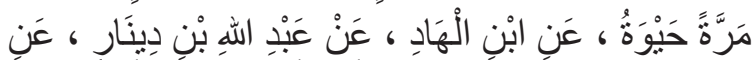

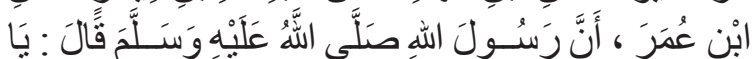

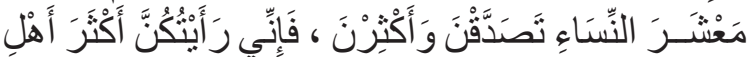

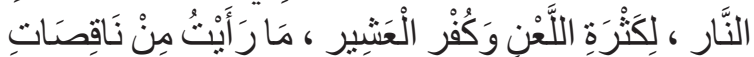

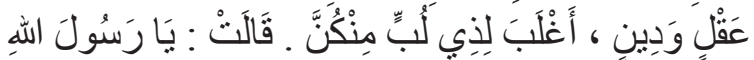

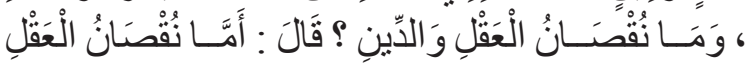

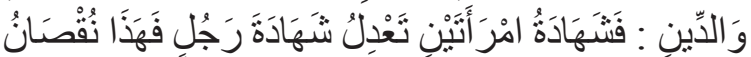

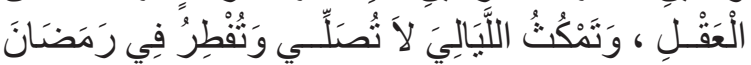

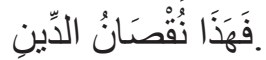

9. Kitab Sunan al-Dârimî Bab al-khaid Tasma'u al-Sajdah fa lâ Tasjud

أخبرنا أبو زيد سعيد بن الربيع ثنا شعبة عن الحكم قال

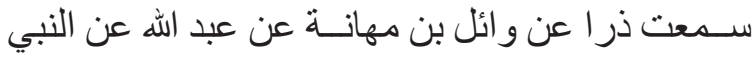

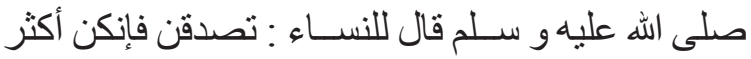

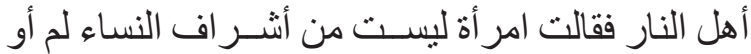

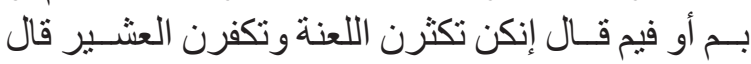

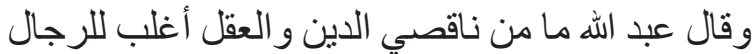

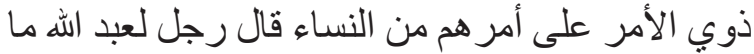

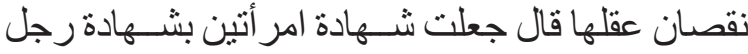

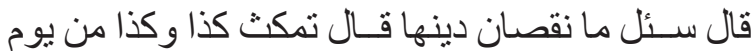
وليلة لا تصلي لله صلاة.

Dari beberapa teks hadis di atas menunjukkan, bahwa pada periwayat generasi sahabat, hadis tersebut diriwayatkan oleh tiga orang sahabat, yaitu 'Abdullâh Ibn 'Umar, Abû Hurairah, dan Abû Sa'id al-Khudrî. Hadis yang diriwayatkan oleh Abû Sa'id al-Khudrî hanya diriwayatkan oleh al- Bukhârî. Dari periwayatan Abû Hurairah, diriwayatkan oleh al-Nasâ'î dan al-Turmudzî. Sedangkan pada julur periwayatan 'Abdullâh Ibn 'Umar, diriwayatkan oleh al-Bukhârî, Muslim, Ibn Mâjah, Ahmad Ibn Hanbal, al-Dârimî dan Abû Dâwud.

Dari penelusuran matan dapat diketahui, bahwa hadis di atas diriwayatkan secara makna. Teks matan hadis di atas menunjukkan adanya redaksi matan yang berbeda. Riwayat yang dikemukakan oleh 'Abdullâh Ibn 'Umar yang diriwayatkan oleh Ibn Mâjah, Muslim, Ahmad Ibn Hanbal dan riwayat Abû Sa'id al-Khudrî yang diriwayatkan oleh al-Bukhârî menunjukkan bahwa Rasulullah SAW menyampaikan hadis tersebut ketika beliau melewati sekelompok kaum perempuan ketika beliau akan melaksanakan shalat Idul Adha atau Idul Fitri.

Sedangkan riwayat dari 'Abdullah Ibn 'Umar yang diriwayatkan oleh Al-Dârimî menjelaskan bahwa Rasulullah SAW menyampaikan kepada perempuan tanpa disebutkan peristiwanya. Kemudian seorang laki-laki menanggapi riwayat 'Abdullâh Ibn 'Umar dan menanyakan kepada 'Abdullâh Ibn 'Umar tentang yang dimaksud kekurangan akal dan agama perempuan. Yang menjelaskan tentang maksud kekurangan akal dan agama perempuan adalah 'Abdullâh Ibn 'Umar. Sementara riwayat dari Abû Hurairah yang diriwayatkan oleh al-Nasâ'î menjelaskan bahwa Nabi SAW menyampaikan tentang masalah kekurangan akal dan agama perempuan ketika beliau kembali dari shalat subuh kemudian menemui para perempuan di masjid. Namun, riwayat dari Abû Hurairah yang diriwayatkan oleh al-Nasâ'î menjelaskan bahwa Rasulullah menyampaikan hadis ini ketika beliau sedang berkhutbah.

Redaksi matan dalam riwayat Muslim relatif mirip dengan riwayat Ibn Mâjah, dibanding dari 
periwayatan yang lain. Jalur periwayatan Ibn Mâjah sama dengan jalur periwayatan Imâm Muslim, yaitu dari Ibn 'Umar, 'Abdullâh bin Dinâr, Yazîd bin 'Abdullâh bin al-Had, Laits bin Sa'ad, Muhammad bin Rumh. Setelah penulis melakukan penelitian sanad pada hadis riwayat Ibn Mâjah dan Muslim, hadis ini telah mencukupi syarat ke-s $\underline{\underline{h}} \underline{\underline{i}} \underline{h}$-an hadis dari segi sanad. ${ }^{13}$

\section{Penelitian Matan Hadis Perempuan Lemah Akal}

Penelitian matan ini menggunakan teori Metodologi Kritik Matan Hadis yang dikemukakan oleh al-Adlabi dalam bukunya Manhaj Naqd al-

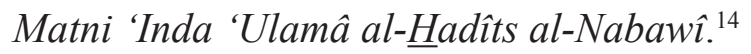

\section{Matan Hadis Tidak Bertentangan dengan Ayat-ayat al-Qur'an}

Dalam al-Qur'an tidak dijumpai ayat yang menjelaskan tentang kelemahan akal perempuan. Sebaliknya banyak dijumpai ayat-ayat yang menyamakan antara laki-laki dan perempuan. Di antaranya adalah Surat al-Ahzâb ayat 35 dan Surat al-Hadîd ayat 12 sebagai berikut:

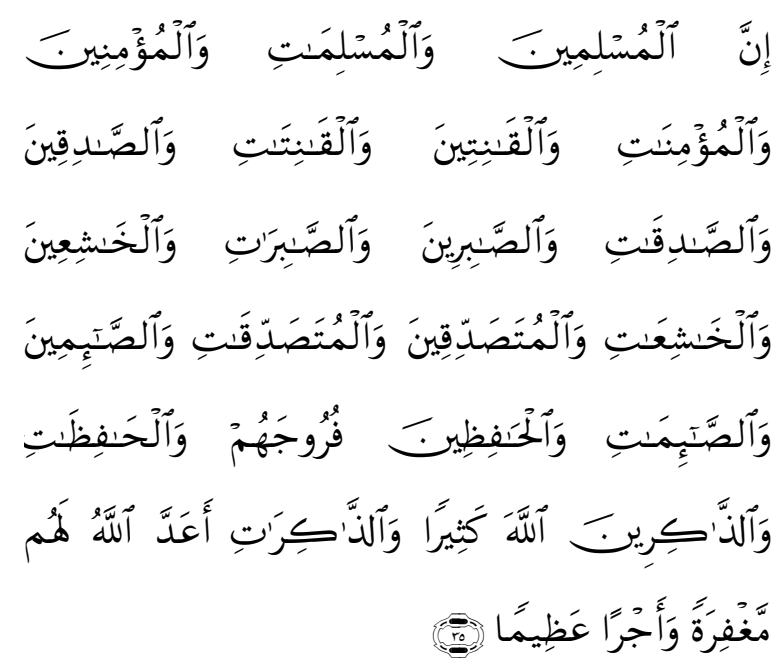

\footnotetext{
${ }^{13}$ Al-Imâm Syams al-Dîn Muhamammad bin Aḥmad bin 'Utsmân Al-Dzahabî, Siyâr A'lâm al-Nubalâ'; (Mesir: Al-Maktabah alTawfiqiyyah, tt); Jamâl al-Dîn Abî al-Hajjâj Yûsuf al-Mizî, Tahdzîb al-Kamâl fî̀ Asmâ' al-Rijâl; (Beir ut: Muassasah alRisalah, 1983); Syamsuddîn al-Dzahabî, Târikh al-Islâm wa Wafayât al-Masyâhir al-'A'lâm; (T.tp: Dâr al-Gharb al-Islâmî, $\mathrm{tt})$.

${ }^{14}$ Salâh al-Dîn ibn Ahmad al-Adabî, Manhaj Naqd al-Matn.
}

Artinya: "Sesungguhnya laki-laki dan perempuan yang muslim, laki-laki dan perempuan yang mukmin, laki-laki dan perempuan yang tetap dalam ketaatannya, laki-laki dan perempuan yang benar, lakilaki dan perempuan yang sabar, lakilaki dan perempuan yang khusyuk, lakilaki dan perempuan yang bersedekah, laki-laki dan perempuan yang berpuasa, laki-laki dan perempuan yang memelihara kehormatannya, laki-laki dan perempuan yang banyak menyebut (nama) Allah, Allah telah menyediakan untuk mereka ampunan dan pahala yang besar."

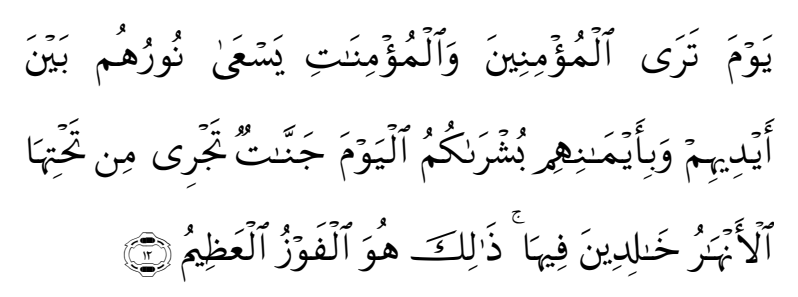

Artinya: "(yaitu) pada hari ketika kamu melihat orang mukmin laki-laki dan perempuan, sedang cahaya mereka bersinar di hadapan dan di sebelah kanan mereka, (Dikatakan kepada meraka): «Pada hari ini ada berita gembira untukmu, (yaitu) syurga yang mengalir di bawahnya sungaisungai, yang kamu kekal di dalamnya. Itulah keberuntungan yang besar".

Perempuan di dalam al-Qur'an mendapat perhatian yang sangat dominan, bahkan lebih dari sepuluh surat di dalam al-Qur'an berbicara tentang segala permasalahan hukum yang berhubungan dengan perempuan. AlQur'an juga meletakkan prinsip-prinsip persamaan antara laki-laki dan perempuan memiliki kedudukan yang sama, sebab tirai pemisah antara seseorang dengan yang lain menurut al-Qur'an adalah Taqwa. Dalam surat al-Hujurat ayat 13 disebutkan sebagai berikut: ${ }^{15}$

\footnotetext{
${ }^{15}$ Ibrahim Hosen dan Ahmad Munif Suratmaputra, al-Qur'an dan Peranan Perempuan dalam Islam (Jakarta: IIQ Jakarta, 2007), 22-23.
} 


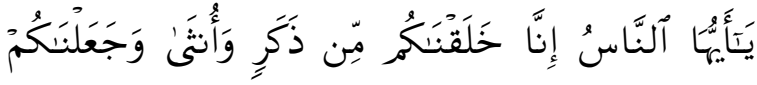

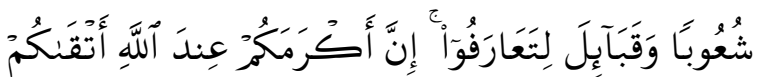
إِنَّ اللَّهَ عَلِيمُ خَبِير

Artinya: Hai manusia, Sesungguhnya Kami menciptakan kamu dari seorang laki-laki dan seorang perempuan dan menjadikan kamu berbangsa-bangsa dan bersuku-suku supaya kamu saling kenal-mengenal. Sesungguhnya orang yang paling mulia di antara kamu di sisi Allah ialah orang yang paling taqwa di antara kamu. Sesungguhnya Allah Maha mengetahui lagi Maha Mengenal.

Pada surat al-Nisâ' ayat 32 menegaskan:

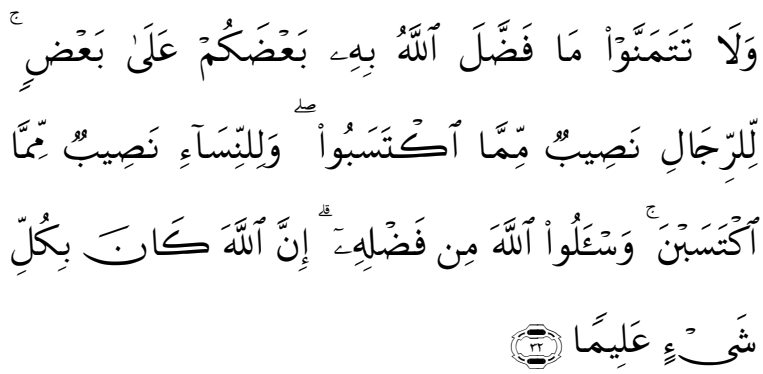

Artinya: "Dan janganlah kamu iri hati terhadap apa yang dikaruniakan Allah kepada sebahagian kamu lebih banyak dari sebahagian yang lain. (Karena) bagi orang laki-laki ada bahagian dari pada apa yang mereka usahakan, dan bagi para wanita (pun) ada bahagian dari apa yang mereka usahakan, dan mohonlah kepada Allah sebagian dari karunia-Nya. Sesungguhnya Allah Maha Mengetahui segala sesuatu”.

Ayat ini menunjukkan bahwa dalam muamalah, tidak ada perbedaan antara pria dan wanita yang cerdas untuk mencari rezeki dan usaha serta bebas pula bertindak terhadap hasil usahanya tersebut. ${ }^{16}$
2. Matan Hadis Tidak Bertentangan dengan Hadis $\underline{S} a \underline{h} \underline{\hat{h}} \underline{h}$ dan Sirah Nabawiyah yang Sahîh

Dalam beberapa riwayat hadis dijelaskan bahwa perempuan memperoleh posisi terhormat pada masa Rasulullah SAW. 'Umar bin Khattab bahkan memberi kesaksian dalam hal ini, sebagaimana sudah dijelaskan di bagian pendahuluan tulisan ini.

Pada masa generasi sahabat, kaum wanita tidak segan-segan untuk menanyakan langsung hukum-hukum agama kepada Nabi SAW. mengenai masalah-masalah yang mereka alami, apabila mereka merasa ragu terhadap jawaban atau fatwa yang diberikan oleh orang lain, atau apabila mereka tidak puas akan jawaban atau fatwa yang diberikan selain Rasulullah. Mereka ini sangat detail dalam mengajukan pertanyaan sehingga mereka benar-benar yakin. Demikian itulah sikap wanita cerdas dan benar-benar sadar akan ajaran agamanya. ${ }^{17}$

Uraian di atas menjelaskan bahwa para sahabat perempuan adalah orang-orang yang cerdas, smart, dan berakhlak mulia, bukan orang-orang yang lemah akalnya dan agamanya.

\section{Matan Hadis Tidak Bertentangan dengan}

\section{Akal, Indra dan Sejarah}

Hasil test IQ yang dilakukan terhadap 489 siswa menengah pertama di salah satu sekolah swasta di daerah Ciputat, Tangerang Selatan, terdiri dari 268 laki-laki, 230 perempuan menunjukkan, 93 siswa perempuan memiliki IQ di atas 100, 89 siswa laki-laki memiliki IQ di atas 100. Selebihnya rata-rata memiliki IQ 80-90. Data ini menunjukkan bahwa tidak ada perbedaan kecerdasan antara laki-laki dan perempuan. Kecerdasan seseorang tidak ada hubungannya dengan jenis kelamin. Sementara fakta di masyarakat juga menunjukkan bahwa

${ }^{17}$ Muhammad Ali Al-Hasyimy, Jatidiri Wanita Muslimah (Jakarta: Pustaka Al-Kautsar, 2003) 117. 
dijumpai banyak perempuan yang memiliki kemampuan sama bahkan melebihi laki-laki dalam beberapa bidang.

Tujuh atau delapan orang dari 10 besar/ ranking di sekolah-sekolah didominasi oleh anak perempuan, sehingga tidak mengherankan banyak fakultas-fakultas sekarang ini dibanjiri oleh mahasiswa perempuan. Mereka dapat mengalahkan dominasi laki-laki. Bahkan pada fakultas tertentu, Fakultas Sastra, Ilmu Pendidikan, Ekonomi, Keperawatan dan Kesehatan, hampir $75 \%$ mahasiswanya adalah perempuan. ${ }^{18}$

Sejak zaman abad ketiga Islam, sekitar sepuluh wanita dalam satu periode seratus tahun yang dapat dikenali bahwa mereka itu adalah penyampai ilmu pengetahuan. Mereka ada yang hamba sahaya, ada pula yang dari keluarga raja, tetapi kebanyakan berasal dari kelas menengah yang berpendidikan, termasuk dua putri hakim. ${ }^{19}$ Jika para perawi wanita dari generasi pertama menyampaikan informasi yang mereka peroleh sematamata karena mereka dekat dengan sumber atau ahli-ahli terpercaya, maka wanitawanita dari generasi terkemudian yang luas pengetahuannya adalah ulama dan guru. ${ }^{20}$

Di kalangan banyak wanita alim yang direkam dalam kamus-kamus biografi, pengetahuan tentang hukum Islam disebutkan dalam sekitar dua belas kasus, dan ada empat wanita yang bertindak sebagai mufti. Relatif banyaknya wanita yang belajar hukum berlangsung sejak dari generasi-generasi awal sampai abad kedua belas/ketujuh belas, dan mereka bertugas di berbagai pusat ilmu Islam. Dengan demikian, wanita tidak sepenuhnya tersingkir dari dunia ahli hukum, justru pastisipasi wanita tampaknya luar biasa.

${ }^{18}$ Nelsi Arisandy, "Pendidikan dan Karir Perempuan dalam Perspektif Islam,” Marwah XV, no. 2 (2016): 126.

${ }^{19}$ Ruth Roded, Kembang Peradaban Citra Wanita di Mata Para Penulis Biografi Muslim (Bandung: Mizan. 1995), 122.

${ }^{20}$ Ibid., 123.
Seperti telah kita ketahui, 'Aisyah, 'Amra binti 'Abdurrahman, Hafshah binti Sirin, dan wanita-wanita lain dari generasi pertama dan kedua, terkenal sebagai ahli hukum dan dilukiskan memberikan fatwa dalam masalahmasalah hukum. ${ }^{21}$

Selain itu, perempuan pada masa Rasulullah SAW memiliki peran besar dalam meriwayatkan hadis. 132 orang sahabat perempuan terlibat dalam periwayatan hadis dari 1046 sahabat yang meriwayatkan hadis dalam al-kutub al-tis'ah. Jumlah ini sangat besar untuk masa-masa awal sejarah Islam masa Rasulullah SAW., mengingat peralihan kedudukan perempuan dari masa jahiliyah. Bahkan 'Âisyah menduduki peringkat ketiga untuk sahabat yang paling banyak meriwayatkan hadis setelah Abû Hurairah dan 'Abdullâh ibn 'Umar. ${ }^{22}$

Zaenab, istri 'Abdullâh ibn Mas'ud adalah perempuan bekerja yang menghidupi keluarganya dengan hasil keterampilannya. Ketika ia menyatakan hal tersebut kepada Rasulullah SAW, Rasul menjawab, "Kamu mendapatkan pahala dari apa yang kamu nafkahkan untuk mereka". Bahkan dalam riwayat lain Zaenab dan juga para perempuan lain disuruh oleh Rasul untuk bersedekah, sebagaimana yang diriwayatkan dalam $\underline{S} a \underline{h} \underline{i} \underline{h}$ Bukhârî, no. 1462:

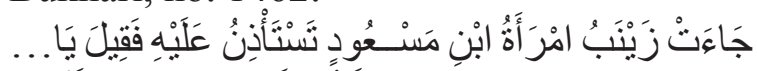

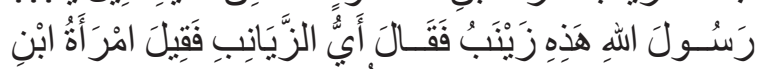

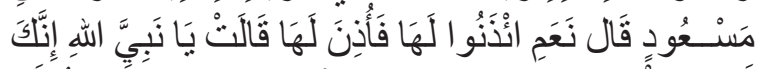

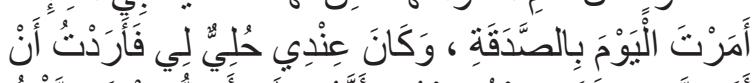

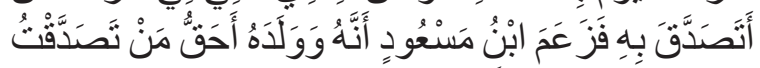

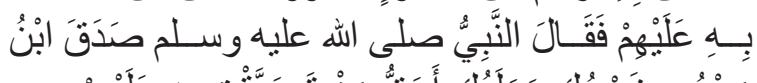

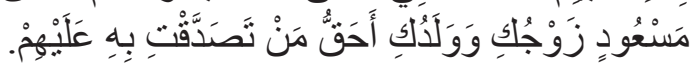

Artinya : “ ... datang Zainab istri Ibnu Mas'ud meminta izin kepadanya (Rasul), lalu berkata: 'Wahai Rasul ini adalah Zainab'. Rasul

\footnotetext{
${ }^{21}$ Ibid., 148.

${ }^{22}$ Agung Danarta, Perempuan Periwayat Hadis, 6, dan Ibn Salâh,

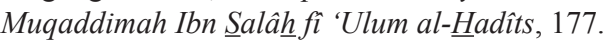


bertanya: 'Zainab siapa?'. Berkata Zainab: 'Zainab istri Ibnu Mas'ud'. Rasul berkata: 'Ya, silahkan.' Maka dia diizinkan lalu berkata: 'Wahai Nabi Allah, sungguh Anda hari ini sudah memerintahkan sedekah, sedangkan aku memiliki emas yang hendak aku zakatkan, namun Ibnu Mas'ud mengatakan bahwa dia dan anaknya lebih berhak terhadap apa yang akan aku sedekahkan ini dibandingkan mereka (mustahiq). Maka Nabi bersabda: 'Ibnu Mas'ud benar, suami dan anak-anakmu lebih berhak kau berikan sedekah dari pada mereka'."

\section{Matan Hadis Tidak Menunjukkan} Ungkapan yang Serampangan, Tidak Menunjukkan Makna yang Rendah

Nabi Muhammad SAW memiliki akhlak yang sangat mulia. Bahkan istrinya, Siti 'Âisyah RA mengatakan apabila ingin mengetahui akhlak Rasulullah SAW, maka akhlaknya Rasul adalah al-Qur'an. 'Âisyah RA menceritakan saat Rasulullah pulang ke rumah, 'Âisyah memberikan minum kepada Rasul. Ketika Rasul meminumnya, Rasul merasakan asin dalam minumannya. Kemudian Rasulullah memanggil 'Âisyah: "Ya Humaira, kamu haus tidak? Ayo temani saya minum." Ketika 'Âisyah ikut minum bersama Rasul, 'Âisyah ikut merasakan asin dalam minumannya. Rasul tidak menegurnya, apalagi memarahinya. Dalam riwayat disebutkan, bahwa Abû Bakar memarahi 'Âisyah dan budak yang sedang bernyanyi dan bermain rebana sehingga terdengar berisik, sementara Rasul sedang beristirahat. Rasul justru menegur Abû Bakar dan membiarkan mereka bernyanyi dan bermain rebana, sebagaimana yang dijelaskan dalam hadis riwayat Imam al-Bukhârî dan Muslim meriwayatkan sebagai berikut:

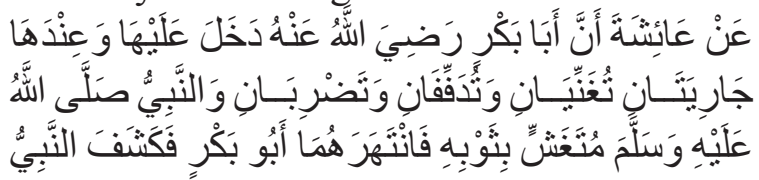

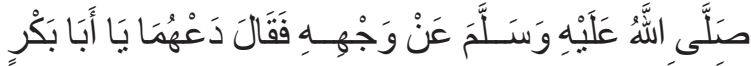

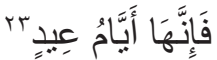

Artinya: "Diriwayatkan dari 'Âisyah bahwa pada suatu hari, Abû Bakar menemui 'Aisyah, ketika itu ia bersama dua hamba sahaya perempuan yang sedang bernyanyi sambil memukul rebana, padahal waktu itu Rasulullah $S A W$. sedang tiduran dengan

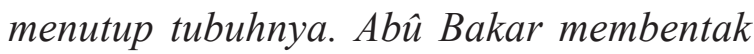
kedua hamba sahaya perempuan tersebut, kemudian Rasulullah SAW. membuka kain yang menutup muka Beliau dan berkata: "Biarkan mereka berdua wahai Abû Bakar, karena hari ini adalah hari raya" (Muttafaq 'Alaih).

Sikap memperlakukan dan mempergauli dengan baik yang dimiliki oleh Rasululah SAW. tidak hanya terbatas pada para sahabat beliau saja. Akan tetapi mencakup semua kaum perempuan, saudara mara, orang lain dan juga budak-budak kecil, baik itu dilakukan ketika berada dalam perjalanan ataupun tidak. Di antara bukti bahwa Rasulullah SAW begitu memperhatikan tentang hal mempergauli istri dan keluarga dengan baik dan lembut adalah riwayat yang mengatakan bahwa Rasul tidak pernah marah kepada istri-istri beliau ketika mereka mengoreksi ucapan beliau, dan juga ada di antara mereka yang menjauhi beliau selama satu hari satu malam. Pada suatu ketika Rasulullah SAW. berkata kepada 'Âisyah RA: "Sesungguhnya aku mengetahui perbedaan kamu, apakah kamu sedang marah atau tidak." "Âisyah RA berkata: "Bagaimana cara baginda mengetahuinya?" Beliau berkata: "Jika kamu sedang tidak marah, maka kamu akan berkata: "Tidak, demi Tuhan Muhammad." Dan jika kamu sedang marah, maka kamu akan berkata: "Tidak, demi Tuhan

\footnotetext{
${ }^{23}$ Muhammad bin Ismâ'îl Abû 'Abdullâh al-Bukhârî al-Ju'fî,
} Sahîh Bukhârî (Riyâd: Maktabah al-Rasyid, 2006), 185. 
Ibrâhîm." "Âisyah RA menjawab: "Baginda benar, ketika saya marah, maka saya tidak akan menggunakan namamu."

Rasulullah SAW selalu memberi wasiat agar mempergauli para istri dengan baik, beliau menjelaskan bahwa sikap mengajak bercanda dan bermain kepada seorang istri merupakan sikap yang dianjurkan, dan bukan merupakan sebuah sikap yang tercela. Beliau bersabda:

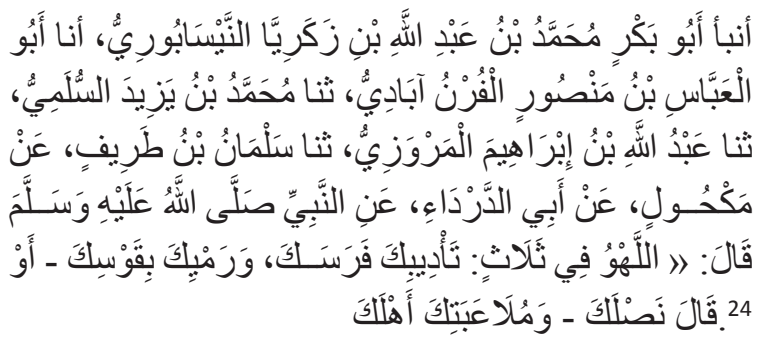

Artinya: “...Tiada hiburan dan permainan (yang diperbolehkan) kecuali dalam tiga hal, melatih kuda, memanah dan mengajak bercanda istri."

Dalam riwayat lain dijelaskan bahwa seorang sahabat, yaitu Anas bin Mâlik sebagai pelayan Rasul, menjadi saksi bahwa Rasul tidak pernah sekalipun menegur, membentak atau berkeluh kesah atas pekerjaannya, apalagi sampai mencela dan memarahi Anas bin Mâlik.

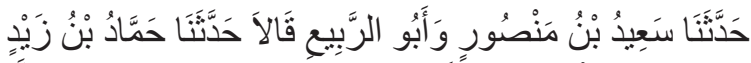

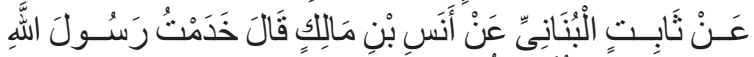

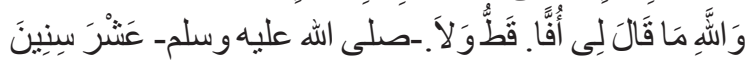

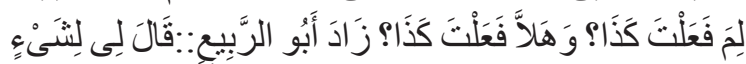

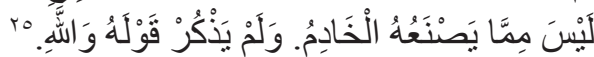

Artinya: "Saya menjadi pembantu Rasulullah SAW. selama sepuluh tahun, demi Allah beliau tidak pernah mencelaku sekalipun,

${ }^{24}$ Abû Ya'qûb Ishâq bin Abî Ishâq Ibrâhîm bin Muhammad ibn 'Abd al-Rahmmâ al-Sarkhosî al-Hurwî al-Qurrâb, Fadâailu al-Rumî fi Sabîlillâh, juz 1 (al-Ardan: Maktabah al-Manâr, 1989), 54.

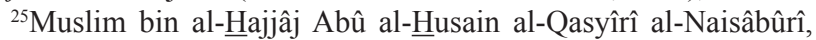
Sahîh Muslim (Beirut: Dâr Ihyâ' al-Turâts al-'Arabî, t.t), 1804. juga tidak pernah berkata kepadaku 'ah', tidak berkata atas yang saya lakukan 'kenapa kau melakukannya' dan tidak pula berkata atas sesuatu yang tidak saya lakukan, 'kenapa kau tidak melakukannya'..."

Sikap memperlakukan dan mempergauli orang lain dengan baik dan ramah tidak akan dapat dilakukan kecuali oleh orang yang memiliki akhlak dan perilaku yang baik serta lurus. Rasulullah SAW tidak pernah mengatakan perkataan secara serampangan untuk mendatangkan hal-hal yang menakjubkan yang tidak dapat dicerna akal sehat, baik maknanya atau lafadznya. Berkaitan dengan masalah ini, rasanya sulit untuk diterima bahwa Rasulullah menyampaikan kepada para perempuan bahwa mereka adalah makhluk yang kurang akal dan agamanya, tetapi mampu mengalahkan ketangguhan laki-laki yang cerdas, seperti dalam teks hadis berikut:

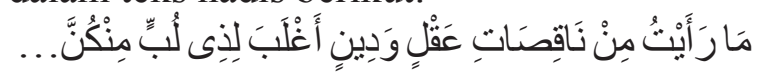

Artinya: “...dan tidaklah aku pernah melihat (seseorang di antara kalian para wanita yang lemah akal dan agamanya, lebih berakal dari (seorang laki-laki) yang berakal."

\section{Kesimpulan}

Hadis yang menjustifikasi bahwa kaum perempuan adalah makhluk yang lemah akalnya, kurang agamanya, dan penghuni neraka terbanyak adalah tidak memenuhi kriteria ke- $\underline{s} a \underline{h} \underline{h} \underline{h}$-an matan hadis berdasarkan metodologi Salahudin ibn Ahmad al-Adlabi. Maka dari itu, hadis tersebut dinilai tidak otentik, karena hadis ini:

1. Matan hadis bertentangan dengan ayat-ayat al-Qur'an;

2. Bertentangan dengan hadis $\underline{s} a \underline{h} \underline{\hat{l}} \underline{h}$ dan sirah nabawiyah yang $\underline{s} a \underline{h} \underline{i} \underline{h}$;

3. Bertentangan dengan akal, indra dan fakta sejarah; dan

4. Matan hadis ini juga tidak menunjukkan 
sikap dan kesantunan Rasulullah SAW dalam bertutur kata.

\section{Daftar Kepustakaan}

al-Aㅁabî, Salâh al-Dîn ibn Ahmad. Manhaj Naqd al-Matn 'inda 'Ulamâ al- $\underline{\text { Hadîts }}$ al-Nabawî. Beirut: Dâr al-Ifaq al-Jadîdah, 1983.

. Metodologi Kritik Matan Hadis Terj. dari bahasa Arab oleh Qodirun Nur dan Ahmad Musyafiq. Jakarta: Gaya Media Pratama, 2004.

Agung Danarta. Perempuan Periwayat Hadis. Yogyakarta: Pustaka Pelakar, 2013.

al-Albânî, Muhammad Nâsir al-Dîn. Riyâdh: Maktabah al-Ma'ârif, 1997 M/1417 H.

al-Bukhârî, Abî 'Abdillâh Muhammad bin Ismâ'îl bin Ibrâhîm bin al-Mughîrah al-Ju'fî. Sahîh al-Bukhârî. Riyâd: Maktabah alRasyid, 2006.

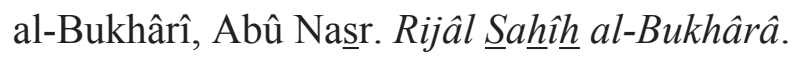

al-Dzahabî, al-Imâm Syams al-Dîn Muhammad bin Ahmad bin 'Utsmân. Siyâr A'lâm al-Nubalâ'. Mesir: Al-Maktabah alTawfiqiyyah, t.t.

al-Dzahabî, Syamsuddîn. Târikh al-Islâm wa Wafayât al-Masyâhir al- 'A'lâm. T.tp: Dâr al-Gharb al-Islâmî, t.t.

al-Hasyimy, Muhammad Ali. Jatidiri Wanita Muslimah. Jakarta: Pustaka Al-Kautsar, 2003.

Ibrahim Hosen Suratmaputra dan Ahmad Munif. Al-Qur'an dan Peranan Perempuan dalam Islam. Jakarta: IIQ Jakarta, 2007.
Lia Aliyah al-Himmah. "Kesaksian Perempuan, Benarkah Separuh Laki-laki?," SUPLEMEN Edisi 06, Swara Rahima VIII, no. 25 (2008): 19-20.

M. Hadi Masruri. "Peran Sosial Perempuan dalam Islam Kajian Historis-Normatif.” Egalita Jurnal Kesetaraan dan Keadilan Gender VII, no. 1 (2012): 22-42.

al-Mizî, Jamâl al-Dîn Abî al-Hajjâj Yûsuf. Tahdzîb al-Kamâl fî̀ Asmâ' al-Rijâl. Beirut: Muassasah al-Risalah, 1983.

al-Naisâbûrî, Muslim bin alal-Qasyîrî. $\underline{S} a \underline{h} \underline{\imath} \underline{h}$ Muslim. Beirut: Dâr Ihyâ' al-Turâts al-'Arabî, t.t.

Nelsi Arisandy. "Pendidikan dan Karir Perempuan dalam Perspektif Islam." Marwah XV, no. 2 (2016): 126.

al-Qurrâb, Abû Ya'qûb Ishâq bin Abî Ishâa Ibrâhîm bin Muhammad ibn 'Abd alRahmâ al-Sarkhosî al-Hurwî. Fadâilu al-Rumîfî Sabîlillâh. al-Ardan: Maktabah al-Manâr, 1989.

Roded, Ruth. Kembang Peradaban Citra Wanita di Mata Para Penulis Biografi Muslim. Bandung: Mizan, 1995.

Salâh, Ibn. Muqaddimah Ibn $\underline{S} a l a ̂ h \underline{h}$ fì 'Ulum alHadîts. Beirut: Dâr al-Kutub al-'Ilmiyyah, t.t.

Al- Sallabî, Ali Muhammad. Sirâh Nabawiyyah. Terj. dari bahasa Arab oleh Imam Fauji. Jakarta: Beirut Publishing, 2014.

al-Sanadî, Muhammad 'Abid. Tartîb Musnad alImâm al-Syâfi'î. Beirut: Dâr al-Fikr, 1997.

Winsink. Al-Mu'jam al-Mufahras Li Alfāz alHâdits al-Nabawiyyah. Leiden: Maktabah Baril, 1936. 